\title{
The comparison of cognitive dissonance and social exchange styles in depressive disorder patients with healthy individuals
}

\author{
Shaghayegh Shojafard ${ }^{1}$, Majid Saffarinia ${ }^{2}$ \\ 1-MSc in General Psychology, Department of Psychology, North Tehran Branch, Islamic Azad University, Tehran, \\ Iran (Corresponding Author). $\quad$ E-mail: shirin.psychology@gmail.com \\ 2- Professor, Department of Psychology, Payame Noor University, Tehran, Iran.
}

Received: 25/03/2020

Accepted: 22/06/2020

\begin{abstract}
Introduction: Using an inefficient styles of social exchange and cognitive dissonance could lead to negative emotions.

Aim: The aim of this study was to compare the cognitive dissonance and social exchange styles, amongst two groups of women patients with major depressive disorder and normal individuals.

Method: In this causal-comparative study, first, 60 women patients with Major Depressive disorder from 3 psychotherapy centers in Tehran were selected by available sampling method . Then, 60 women who attended in different areas of the city, were selected randomly, so that 120 women, were assessed. Questionnaires of cognitive dissonance and social exchange styles were applied in order to collect data. Data analysis was performed by Kolmogorov- Smirnov, (KStest) and the one-way analysis of variance (ANOVA) test, using SPSS-PC (v.20).

Results: The results indicated that individuals with depression are more likely to be in cognitive arousal state $(\mathrm{P}<0.05)$. While normal individuals were more able to reduce their cognitive dissonance. Equally, in social exchange styles there was a meaningful difference in Mean (average) of individualism and tracking in the two groups. But there was not a meaningful difference between Mean (average) of the fairness, benefit-seeking, individualism, tracking and overinvestment variables.
\end{abstract}

Conclusion: According to the results of this study, in treatment of depressed women, pay attention to arousal and Cognitive dissonance-reducing is needed.

Keywords: Cognitive dissonance, Social exchange, Depression, Exchange styles

How to cite this article : Shojafard Sh, Saffarinia M. The comparison of cognitive dissonance and social exchange styles in depressive disorder patients with healthy individuals. Shenakht Journal of Psychology and Psychiatry. 2020; 7 (3): 124-135 .URL: http://shenakht.muk.ac.ir/article1-922-en.pdf

Copyright (C) 2018 the Author (s). Published by Kurdistan University of Medical Sciences. This is an open access article distributed under the terms of the Creative Commons Attribution-Non Commercial License 4.0 (CCBY-NC), where it is permissible to download, share, remix, transform, and buildup the work provided it is properly cited. The work cannot be used commercially without permission from the journal. 


\title{
بررسى و مقايسهى ناهماهنكى شناختى و سبكهاى تبادل اجتماعى در بيمار ان زن مبتلا به اختلال افسردىى اساسى و زنان سالم
}

\author{
شقايق شجاع فرد'، مجيد صفارى نيا' \\ ا. كارشناسى ارشد روانشناسى عمومى، گروه روانشناسى، واحد تهران شمال، دانشكاه آزاد اسلامى، تهران، ايران (مولف مسئول). \\ ايميل: shirin.psychology@gmail.com \\ r. استاد، كروه روانشناسى، دانشخاه يِيام نور، تهران، ايران.

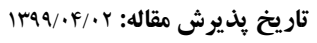

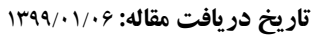

جكيده

مقدمه: اتخاذ سبككهاى تبادل اجتماعى ناكار آمد و ناهماهنكى شناختى مى تواند موجب هيجانهاى منفى گردد. هدف: هدف يُزوهش حاضر عبارت بود از مقايسهى ناهماهنگى شناختى و سبكهاى تبادل اجتماعى در بيماران زن مبتلا به اختلال

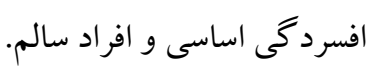

روش: در اين طرح يزوهشى على مقايسهاى ابتدا از ميان مراكز رواندرمانى شهر تهران، سه كلينيك انتخاب و از مراجعه كنندكان زن

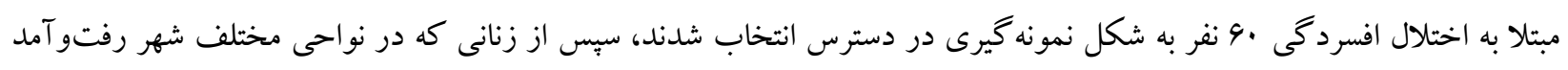

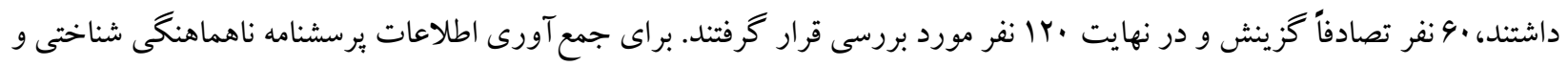

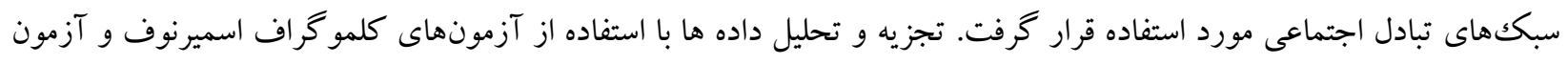
تحليل واريانس يككطرفه (آنوا) در نسخه ·ب نرم افزار

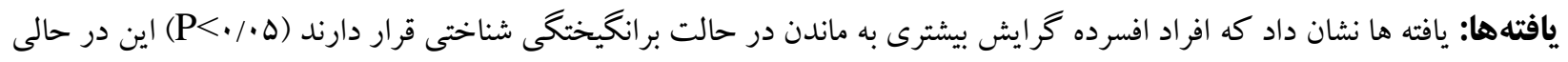

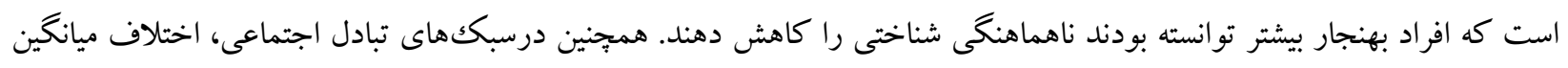

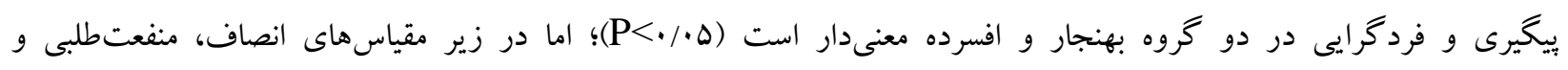

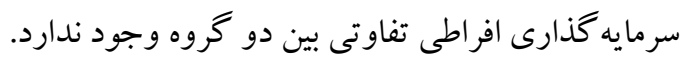

نتيجه كيرى: با توجه به يافتها توصيه مىشود در درمان زنان افسرده نقش برانگيختكى و كاهش ناهماهنكى شناختى مورد توجه قرار كيرد. كليدوازهها: افسردگى، ناهماهنكى شناختى، سبك هاى تبادل اجتماعى 


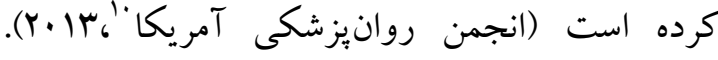
يافتهاى تحقيقاتى عوامل شناختى متعددى را به عنوان ريسك فاكتور شروع و حفظ اختلال افسردگى مشخص نمودهاند كه از جمله آنها مىتوان به افكار اتوماتيكك" طرحواره هاى ناكار آمد ب' و سو گيرى هاى شناختى و و

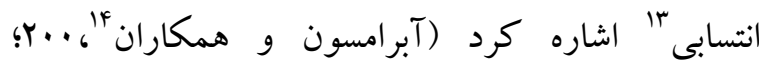
فيكسياس و و همكاران تعارض ها و ناهماهنكى هاى شناختى و تعارض هاى درونى حل نشده هسته ى اصلى بخشى از بيمارىهاى

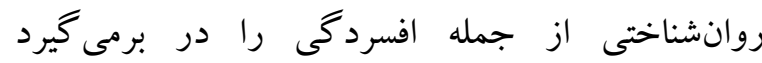

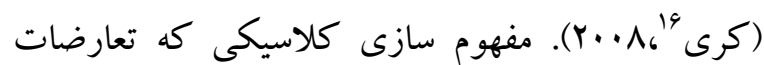
IV درونى را بازنمايى مى كند مفهوم ناهماهنكى شناختى

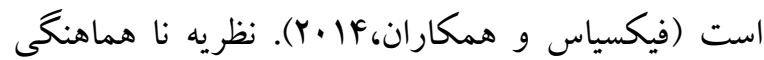
شناختى نخستين بار توسط لئون فستينگر (I9DV) مطرح شد. اين نظريه بيشبينى مى كند كه وقتى فرد دو يا جند

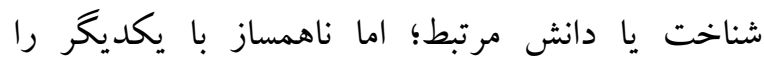
داراست، در او حالتى ناخوشايند ايجاد مى شود. اين حالت ناخوشايند اصطلاحاً (ناهماهنكى) ناميده مىشود. مطابق با نظريه اصلى ناهماهنكى اين حالت ناخوشايند ناهماهنكى، افراد را در يكك وضعيت فيزيولوزيكى مبتنى نه بر برانكيختخى قرار مىدهد كه فرد را براى كاهش ناهمسازى بين شناختها انخيزهمند مى كند (هارمون -

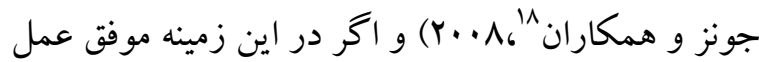
كند و ناهماهنكى كاهش يابد بر انخيختخى نيز كاهش

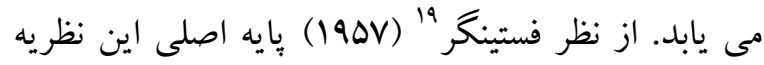

${ }^{10}$ - American Psychiatric Association

11 - Automatic thoughts

12 - Dysfunctional schemas

13 - Attribution bias

14- Abramson et al.

15 - Feixas, G. et al.

16. Carey

${ }^{17}$ - Cognitive dissonance

18 - Harmon-Jones et al

${ }^{19}$ - Festinger, L
مقل مله

اختلالات افسردگى جزو شايعترين و ناتوانكنندهترين اختلالات روانيزشكى در سطح دنياست (شاين و و

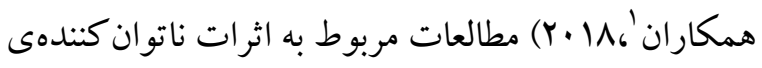
بيمارىهاى سازمان بهداشت جهانى نشان داد كه اختلالات افسردگى يكى از عمدهترين دلايل ناتوانى در سطح دنياست و يكى از بيمارىهايى است كه سهم عمدهاى در اثرات مخرب و ايجاد بدكاركردى در زمينه

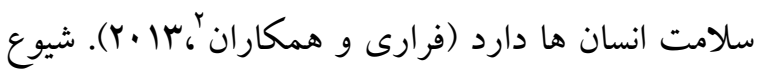
طول عمر اختلالات افسردگى در برخى مطالعات ^, •r/.

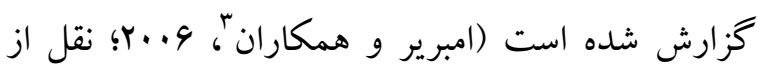

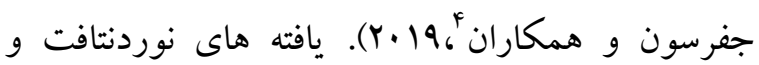
همكارانه (سו.r) حاكى است كه ابتلا به اختلالات افسردگى اميد به زندگى بيماران را كاهش داده است و به صورت ميانگين اين رقم براى زنان rا سال و براى مردان با 19 سال كاهش در اميد زندگى همراه است. حدود يكك سوم از بيماران با اختلالات افسردگى در بلند

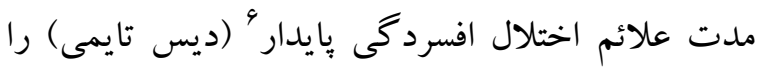

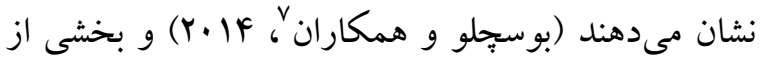
بيماران نيز إيزود افسردگى اساسى را تجربه مى كنتد

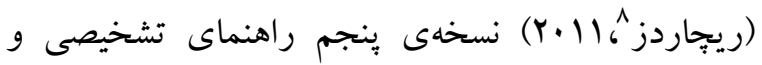

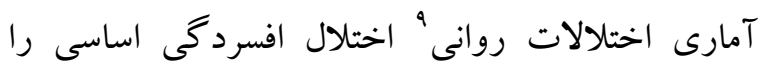
اختلالى با يكك يا جند دورهى افسردگى اساسى بدون سابقهى دورههاى شيدايى، مختلط يا هييومانى تعريف

\footnotetext{
1. Schaich

2- Ferrari AJ et al.

3 - Ebmeier et al.

4- Josefsson, et al.

5 - Nordentoft M, et al.

${ }^{6}$ - Persistent depressive disorder

7- Boschloo L et al.

${ }^{8}$ - Richards D

9- Diagnostic and Statistical Manual of Mental Disorders(5th)DSM-5
} 
هزينه هاى تلاش و منابع در مقابل منافع حاصل از و (Y)

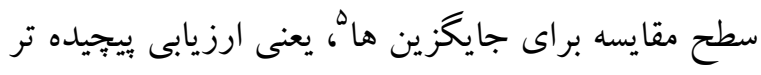
نسبت هزينه - سود رابطه در مقابل نسبت هزينه - سود جايخزين هاى ديخرى كه در دسترس فرد قرار دارد. نتايج حاصل از اين محاسبات تعيين مى كند كه فرد در يكك رابطه يا گروه باقى مى ماند يا خير (ناكس، زاسمن،

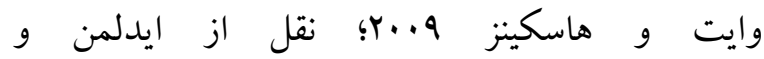

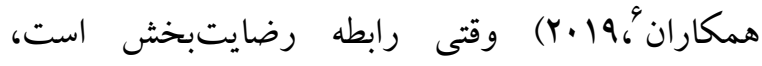
احساس مى كنيم سرمايه گذارى سوددهى داشته و اين سرمايه كذارى تعهد ما را به حفظ رابطه تقويت مى كند؛ اما اگر براى رابطهاى كه نارضايتى به همراه دارد،

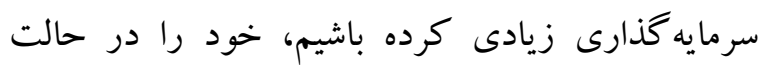
تعارض و تنش ناشى از ناهماهنكى شناختى خواهيم يافت كه اين سبككهاى تبادل اجتماعى معيوب نيز مىتواند منجر به تخريب روابط بين فردى و نهايتاً كاهش خلق به بئ شود (ايدلمن و همكاران، 19. 19) به همين دليل به نظر مىرسد سبك هاى تبادل اجتماعى معيو بـ نقش مهمى در شكل دهى اختلالات خلقى ايفا كند. به همين دليل بررسى آنها در بيماران افسرده امرى است ضرورى. با توجه به موارد ذكر شده بثوهشخر بر آن شد كه در حيطه بالينى اختلال افسردگى (متغير تأثير يذير) كه عوامل متعددى بر آن تأثير مى كذارند، به بررسى تفاوتهاى

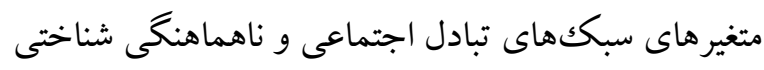
در ميان زنان داراى اختلال افسردگى اساسى و زنان فاقد بيمارى ببردازد و سؤال ئزوهش حاضر عبارت است از اينكه آيا از نظر سبك هاى تبادل اجتماعى و ناهماهنكى

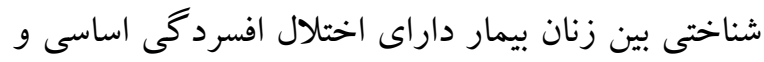
زنان فاقد بيمارى تفاوتى وجود دارد؟

5 - Comparison level for alternatives

${ }^{6}$ - Polina Eidelman et al.
اين است كه انسان هميشه براى حفظ هم سنخى، انسجام يا هارمونى درونى بين عقايد، نكرش ها و ارزشها تلاش مى كند؛ به عبارت ديخر نوعى لهى كشاننده به سوى هماهنكى بين شناخت ها وجود دارد

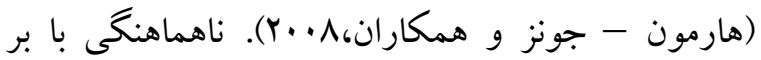
طرف كردن شناختهاى ناهماهنگك، اضافه كردن

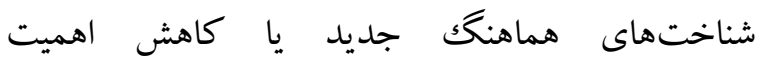

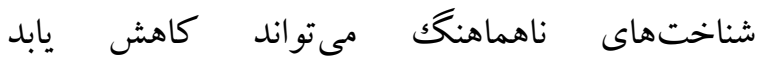

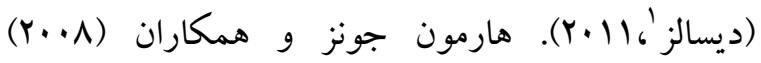
معتقدند كه رفتار كاهش ناهماهنگیى شناختى، رفتارى ساز گارانه و كنشى است و اغلب براى اركانيسم مفيد

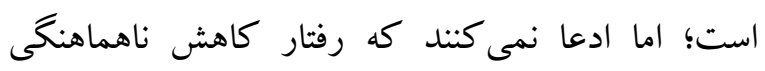
همواره رفتارى كنشى و مفيد است، بلكه شبيه ديخر

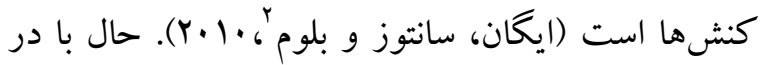
نظر داشتن موارد فوق الذكر به نظر مى رسد نحوه عملكرد بيماران افسرده در مقابله با ناهماهنگى شناختى و برانگيختكى واجد اهميت است و جِندان واضح نيست كه جهه تفاوت هاى ميان زنان افسرده و غير افسرده وجود دارد به همين دليل بثزوهش حاضر بدان مى بردازد. يكى ديخر از متغيرهايى كه به نظر مىرسد در بيماران افسرده نقش ايفا كند تبادل اجتماعى بّاست. نظريه تبادل

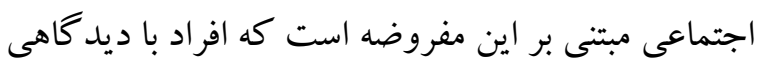
اقتصادى به روابط خود مى نخرند، هزينه هايى آن را بر آورد كرده و با منافع و ياداش هاى حاصل از آن مقايسه

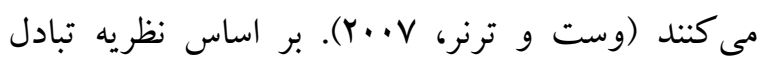
اجتماعى افراد براى تعيين ارزش يك رابطه دو محاسبه انجام مى دهند: (1) سطح مقايسه بُ يعنى ارزيابى مستقيم

\footnotetext{
1- Dessalles J-L

2- Egam, L.C., Bloom, P., \& Santos, L.R.

3 - Social exchange

4- Comparison level
} 
يرسشنامه سبك هاى تبادل اجتماعى!' برسشنامه تبادل روش

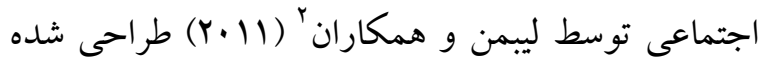
و مشتمل بر OF كويه و ينج خرده مقياس بيخيرى، انصاف، فردگرايى، منفعت طلبى و سرمايه كذارى بن افراطى است. گويه ها در طيف ليكرت ينج درجهاى

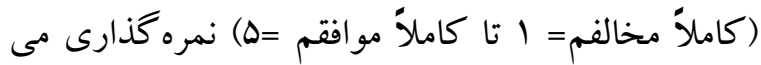
شوند؛ بنابراين، حداقل و حداكثر نمره برابر با ه و و ه

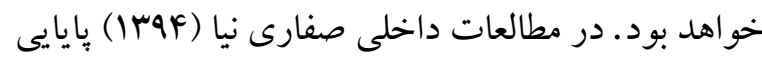
يرسشنامه را با استفاده از روش آلفاى كرون باخ براى كل

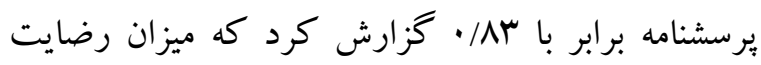
بخشى است. همجنين، نتايج يزٔوهش جهت تعيين روايى

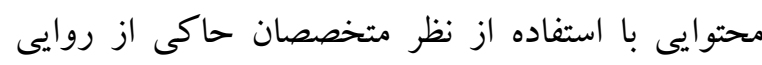
محتو ايى برسشنامه و نتايج تحليل عاملى اكتشافى و تحليل مؤلفههاى اصلى(PC) از طريق جرخش واريماكس مؤيد وجود ينج عامل داراى ارزش ويزه بزركت تر از يكك

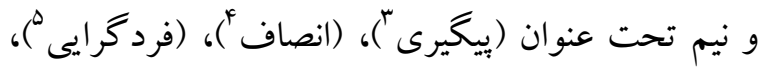

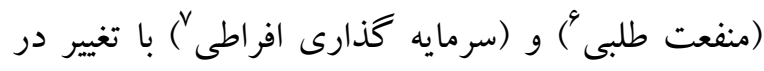
برخى گويه هاى اصلى و حذف سا گويه بوده است. بر اساس نتايج يزوهش صفارى نيا (FوMا) نتايج تحليل

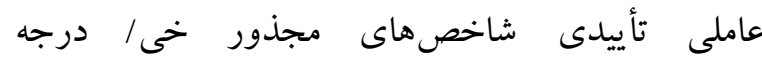
آزادى 46/3= df/x2، شاخص نيكويى برازش GFI

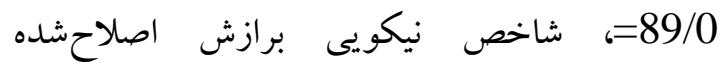
CFI=86/0 شاخص بر ارزش تطبيقى AGFI=86/0

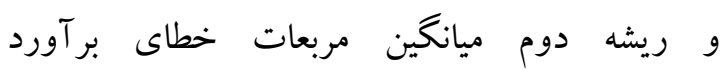

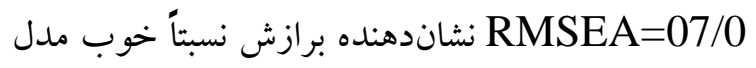

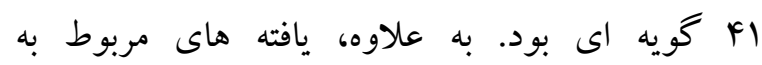

1. Social Exchange Styles scale

2- Leybman, M. J et al.

3 - Tracking

${ }^{4}$ - Fairness

5 - Individualism

6 - Benefit seeking,

${ }^{7}$ - Overinvestment

مطالعه حاضر جزو مطالعات على پِ از وقوع و پِس رويدادى است. جامعه آمارى يُزوهش حاضر شامل

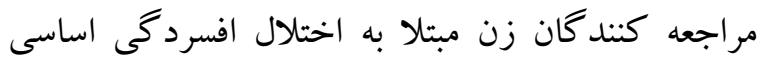
كلينيك هاى مشاوره و رواندرمانى شهر تهران در شش ماهه اول سال وهبا بوده است. براى نيل به اين هدف و بر اساس اصول آمار كاربردى در تحقيق على مقايسه ایى حاضر دو گروه مستقل انتخاب كشته كه بهصورت مساوى تقسيم شدهاند: گروه اول •9 زن مبتلا به اختلال افسردگى اساسى و گروه دوم .4 زن بهنجار. در گروه اول ابتدا از ميان مراكز روانشناسى و مشاوره شهر تهران

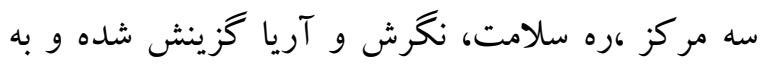
روش نمونه گيرى در دسترس •و نفر از مراجعه كنند كان زن كه در زمان اجراى يثوهش در آن جا تحت درمان

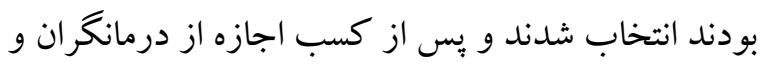

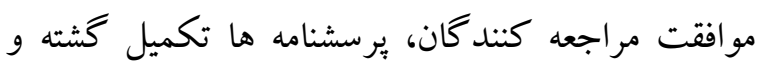
جمع آورى شدند. معيارهاى ورود به بزوهش براى اين كروه عبارت بود از: عدم ابتلاى همزمان به اختلالات روانشناختى، تمايل به تكميل وبرسشنامه و عدم وجود برد اختلالات شخصيت. در گروه دوم نيز از جمعيت زنان بهنجارى كه مراجعه به ادارهها و انستيتو روانيزشكى و بارككهاى شهر تهران از مناطق شمال و جنوب و غرب و و شرق داشتند، ·4 نفر به شيوه تصادفى ساده گزينش شدند (قلمرو مكانى)، سبس از آنان دعوت به همكارى در زمينه ير كردن يرسشنامه ها به عمل آمد و بعد از تكميل به منظور تجزيه و تحليل و مقايسه متغيرهاى ناهماهنكى شناختى و سبكك هاى تبادل اجتماعى در دو گروه موجود، عودت گرديد. 
يرسشنامه با استفاده از روش باز آزمايى برابر با ه/ • و با

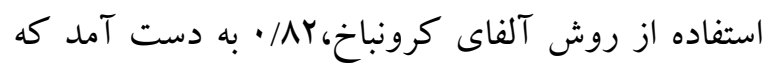
ميزان رضايت بخشى است. به علاوه، ضريب آلفاى

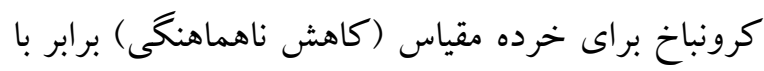
TF آمد كه ميز ان قابل قبولى است.

يافتهها در خصوص سن شركت كنند كان نتايج حاكى از آن بود

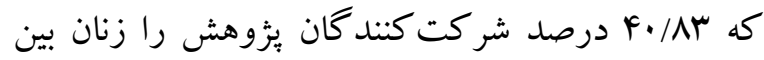

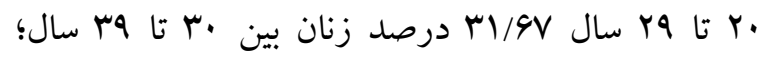

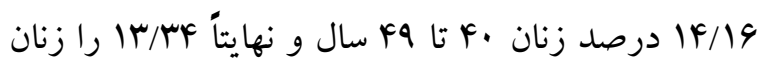
بين •ه تا •و سال تشكيل مىدهند. ه·/ VY/ درصد از شركت كنند كان زير · F سال سن دارند. همجنين نتايج حاكى از آن است كه نسبت سنى بين دو گروه بهنجار و افسرده به مقدار بسيار زيادى يكسان در نظر گرفته شده اله

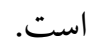

PF/N مر مورد وضعيت تأهل نيز نتايج نشان داد كه

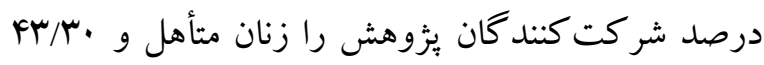
درصد را زنان مجرد تشكيل مىدهند همجنين 1Y/9 درصد از زنان شركت كننده در بثوهش مطلقه بودهاند. همجنين نتايج حاكى از آن است كه نسبت وضعيت تأهل بين دو گروه بهنجار و افسرده به مقدار بسيار زيادى يكسان در نظر كرفته شده است.
هنجارسازى نشان داد كه ميانه نمرات انصاف، منفعت طلبى، فردگرايى، بيگيرى و سرمايه - گذارى افراطى در

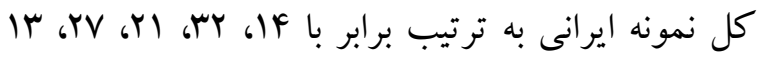
يرسشنامه ناهماهنكى شناختى: برسشنامه برانگيختخى و إنى

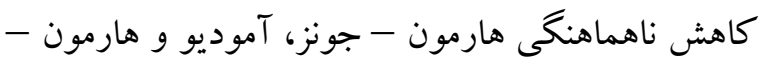

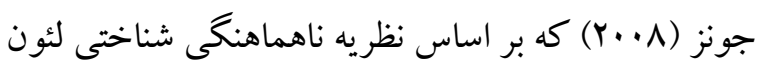

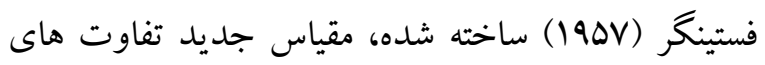
فردى مرتبط با فر آيند ناهماهنگى است كه بر مبناى مدل

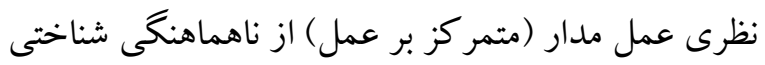
استوار است. اين يرسشنامه از نوع مداد-كاغذى و خود گزارش دهى است، مشتمل بر ها گويه است. گويه هاى

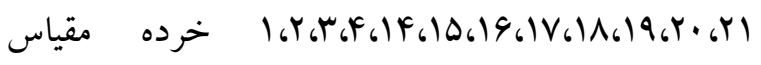

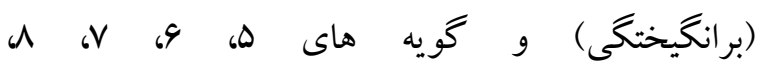

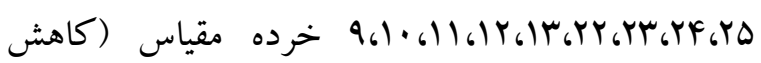
ناهماهنگى) را مى سنجد. نمره گذارى گويه ها بر اساس مقياس ليكرت ينجدرجهاى به صورت (هميشه= ه)،

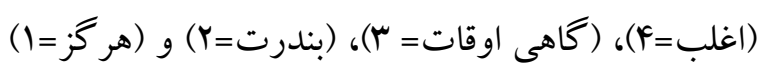
انجام مىشود؛ بنابراين، حداقل و حداكثر نمره كسب شده از اين برسشنامه به ترتيب برابر با هr و ها إ خواهد

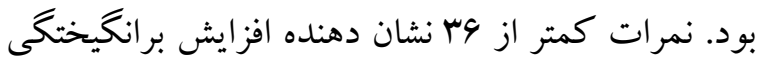
افراطى و افزايش ناهماهنكى و نمرات بيشتر از 94 نشان دهنده كاهش برانگيختكى افراطى و كاهش ناهماهنكى

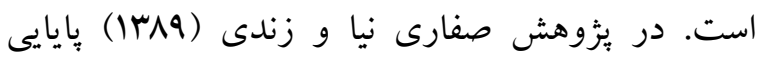

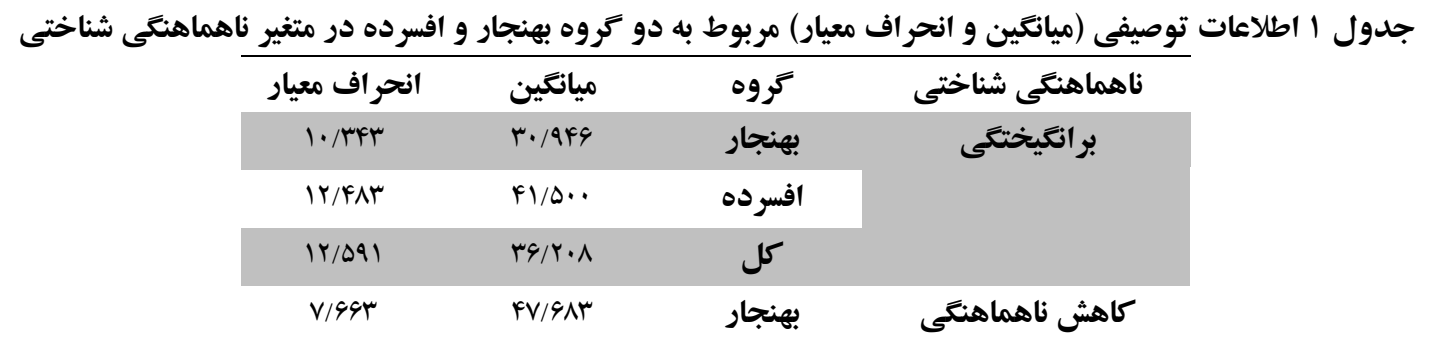




\begin{tabular}{|c|c|c|}
\hline$\Lambda / 99 \Delta$ & FI/VIS & افسرده \\
\hline N/AFr & $F F / V .$. & كل \\
\hline
\end{tabular}

تحليل واريانس يككطرفه براى متغير ناهماهنكى شناختى

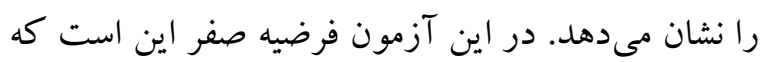

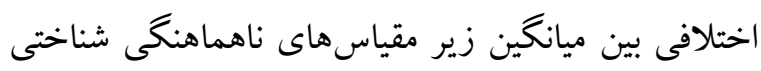

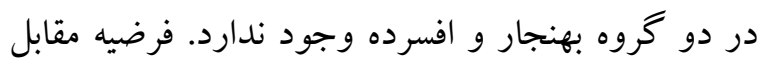
آن است كه بين ميانگين دو گروه اختلاف معنىدارى

$$
\text { وجود دارد. }
$$

نتايج جدول انشان مىدهد كه ميانگين نمره بر انگيختخى در گروه افسرده بيشتر از خروه بهنجار است؛ اما در زير مقياس كاهش ناهماهنگى ميانخين نمره گرووه بهنجار بيشتر از گروه افسرده است.

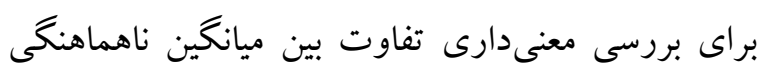
شناختى در دو گرووه بهنجار و افسرده از آزمون تحليل واريانس يككطرفه استفاده شد. جدول r نتايج آزمون

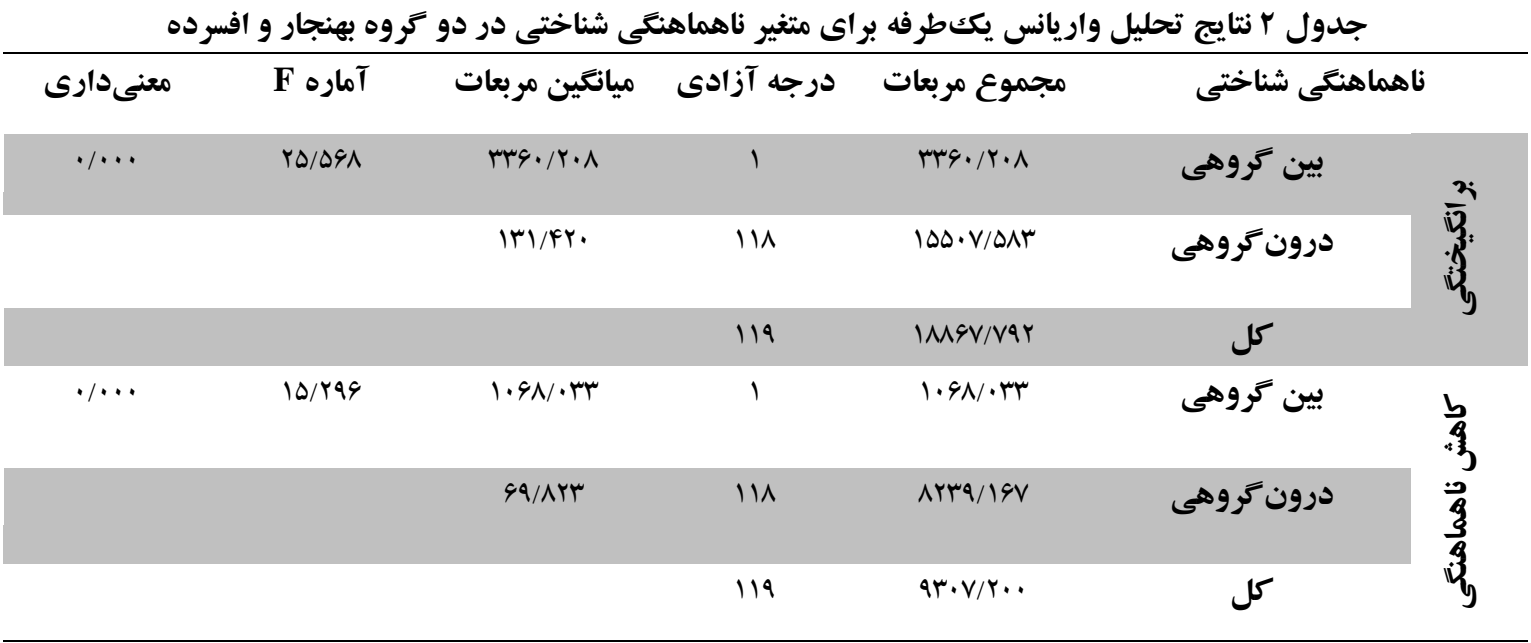

كاهش ناهماهنگى در دو گروه بهنجار و افسرده اختلاف نتايج جدول r نشان مىدهد كه فرضيه صفر مبنى بر

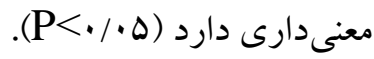
برابرى ميانگين دو گروه بهنجار و افسرده در هر دو زير مقياس رد مىشود يعنى ميانخين بر انخيختخى و همبنين

\begin{tabular}{|c|c|c|c|}
\hline & بادل اجت & ايج تون & \\
\hline انحراف معيار & ميانكين & كروه & تبادل اجتماعى \\
\hline$F / N \cdot r$ & $r r / q .$. & بهنجار & \multirow[t]{3}{*}{ ييكيرى } \\
\hline $91 . V \pi$ & $r \cdot / 919$ & افسرده & \\
\hline$\Delta / 91 Y$ & $r r / F \cdot \Lambda$ & كل & \\
\hline$\Delta / 1 T^{\prime} q$ & $r 9 / 919$ & بهنجار & \multirow[t]{3}{*}{ انصاف } \\
\hline$F / N \mid \Lambda$ & $r \Delta / r 49$ & افسرده & \\
\hline r/QAY & rq/.91 & كل & \\
\hline
\end{tabular}




\begin{tabular}{|c|c|c|c|}
\hline r/IrI & $r \mid / \Delta \wedge r$ & بهنجار & \multirow[t]{3}{*}{ فردكرايى } \\
\hline r/9ᄉr & 19/ADr & افسرده & \\
\hline$r / D F q$ & $r \cdot / \Delta \wedge r$ & كل & \\
\hline G/ATD & $r \cdot / \Delta \wedge r$ & بهنجار & \multirow[t]{3}{*}{ منفعت طلبى } \\
\hline$V / \Delta \Delta r$ & YA/AIQ & افسرده & \\
\hline V/rYY & $r q / V \ldots$ & كل & \\
\hline$r / V \cdot \Lambda$ & 19/11 & بهنجار & \multirow[t]{3}{*}{ سرمايه كذارى افراطى } \\
\hline$r / Y M$ & $10 / 0 \ldots$ & افسرده & \\
\hline$Y / \Delta I V$ & $10 / 119$ & كل & \\
\hline
\end{tabular}

اجتماعى را نشان مىدهد. در اين آزمون فرضيه صفر اين است كه اختلافى بين ميانگين مؤلفهاى تبادل اجتماعى در دو گروه بهنجار و افسرده وجود ندارد. فرضيه مقابل آن است كه بين ميانگين دو گروه اختلاف معنىدارى وجود دارد.
نتايج جدول ب نشان مىدهند كه ميانگين نمره در همه مؤلفهاى سبك تبادل اجتماعى در گرووه بهنجار بيشتر از كروه افسرده است. براى بررسى معنىدارى تفاوت بين ميانگين تبادل اجتماعى در دو گروه بهنجار و افسرده اسر بردي آزمون تحليل واريانس يككطرفه استفاده مى كنيم. جدول F نتايج آزمون تحليل واريانس يككطرفه براى متغير تبادل

جدول f نتايج تحليل واريانس يككطرفه براى متغير تبادل اجتماعى در دو كروه بهنجار و افسرده

\begin{tabular}{|c|c|c|c|c|c|c|}
\hline معنىدارى & Tاره F T & ميانكين مربعات & درجه آزادى & مجموع مربعات & اجتماعى & تباد \\
\hline \multirow[t]{3}{*}{$\cdot / \cdot r$} & $9 / \cdot .49$ & $r q V / \cdots \Lambda$ & 1 & $r g V / \cdots \Lambda$ & بين گروهى & \multirow{3}{*}{ 岁: } \\
\hline & & $r Q / \Delta \cdot \Lambda$ & 111 & HFAI/QAK & درون گروهى & \\
\hline & & & 119 & TVFN/৭9Y & كل & \\
\hline \multirow[t]{3}{*}{$\cdot / \cdot v \cdot$} & $r / r \Delta \Delta$ & $11 / 9 V \Delta$ & 1 & $\Lambda 1 / 9 V \Delta$ & بين گروهى & \multirow{3}{*}{$\begin{array}{l}\overline{9} \\
\overline{9}\end{array}$} \\
\hline & & YF/MFY & 111 & YAVT/TIV & درون گروهى & \\
\hline & & & 119 & rQDr/99r & كل & \\
\hline \multirow[t]{3}{*}{$\cdot / \cdot r$} & $1 . / r 9 V$ & $1 r \cdot / \ldots$ & 1 & $\mid r \cdot / \ldots$ & بين گروهى & \multirow{3}{*}{$\frac{13}{3 j}$} \\
\hline & & $11 / 9 M$ & 111 & Irva/I9V & درون گروهى & \\
\hline & & & 119 & $1 F 99 / 19 \mathrm{~V}$ & كل & \\
\hline \multirow[t]{3}{*}{$\cdot / \backslash \wedge \mid$} & $1 / A \cdot V$ & ar/9Mr & 1 & $9 r / 9 \pi T$ & بين گروهى & \multirow{3}{*}{ 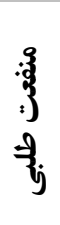 } \\
\hline & & $\Delta 1 / \wedge 1$. & 111 & $911 \mathrm{r} / \Delta \mathrm{V}$ & درون گروهى & \\
\hline & & & 119 & $g r \cdot V / r \ldots$ & كل & \\
\hline
\end{tabular}




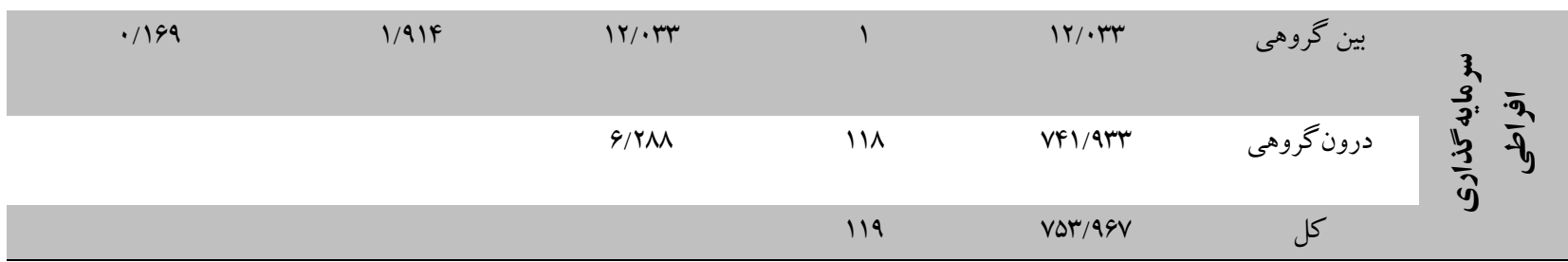

مؤلفههاى سبك تبادل اجتماعى در گروه بهنجار بيشتر از كروه افسرده است؛ به عبارتى فرضيه صفر مبنى بر برابرى ميانگين دو گروه بهنجار و افسرده در هر دو زير مقياس رد مىشود (معنىدارى كمتر از ه• ه • است)، يعنى ميانگين بيخيرى و همجنين فردخرايى در دو گروه بهنجار و افسرده اختلاف معنى دارى دارد؛ اما در زير مقياسهاى انصاف، منفعت طلبى و سرمايه گذارى افراطى فرضيه صفر تائيد مى شود؛ به عبارتى اختلاف معنى دارى بين كروه بهنجار و افسرده در اين زير شاخص ها وجود ندارد. اگر جֶه در حوزه تبادلات اجتماعى و سبككهاى منفى تبادل مطالعات زيادى صورت نكرفته است؛ اما برخى از مطالعات در مورد اهميت سبككهاى تبادل

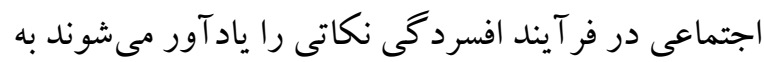
عنوان مثال تحقيق ايدلمن و همكاران (19 (Y) نشان داد كه در شرايط بيش از درمان شناختى رفتارى حمايت اجتماعى يايين و سبككهاى منفى تبادل اجتماعى با سطح بالاتر اضطراب و افسردگى همراه است و در اين رابطه سبككهاى منفى تبادل اجتماعى بيش بينى كننده قوىترى از افسردكى و اضطراب هستند و جالب اينجاست كه ياسخكويى به درمان زمانى قوىتر بود كه سبك هاى منفى تبادل اجتماعى بهتر اصلاح گردد و اين حكايت از نقش مهم سبككهاى منفى تبادل اجتماعى در فرآيند

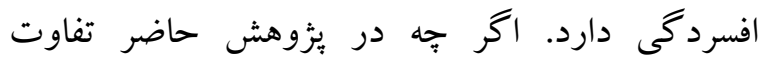
معنادارى بين بيشتر مؤلفههاى تبادل اجتماعى دو گرووه

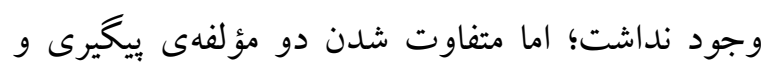

نتايج جدول F نشان مىدهد كه فرضيه صفر مبنى بر برابرى ميانگين دو گروه بهنجار و افسرده در هر زير

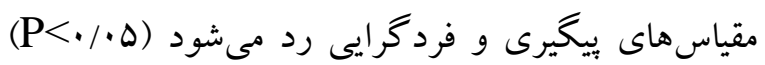
يعنى ميانگين ييخيرى و همجنين فردگرايى در دو گروه بهنجار و افسرده اختلاف معنىدارى دارد؛ اما در زير مقياسهاى انصاف، منفعتطلبى و سرمايه گذارى افراطى فرضيه صفر تائيد مىشود؛ به عبارتى اختلاف معنىدارى بين گروه بهنجار و افسرده در اين زير شاخصها وجود

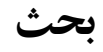
در حيطه مقايسه افراد بهنجار و مبتلايان افسردگى در خصوص متغيرهاى شناختى مختلفى (ازجمله طرحواره ها، خطاها و تحريفات شناختى، عقايد غير منطقى، حافظه و توجه انتخابى و اجزاى شناختى فرآيند انتساب كه همگ مانند ناهماهنكى شناختى مرتبط به ساختار شناختى مىباشند) يثزوهشهايى صورت كرفته است؛ اما در تحقيقات ييشين توجه به تضادهاى شناختى و تعارضهاى

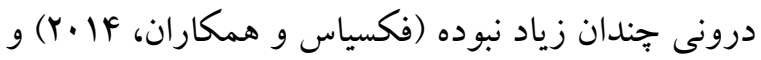
نقش تبادلات اجتماعى به صورت واضح مورد توجه زيادى قرار نخرفته است به همين دليل بزوهش حاضر نيز با هدف بررسى و مقايسهى ناهماهنكى شناختى و سبككهاى تبادل اجتماعى در بيماران زن مبتلا به اختلال افسردگى اساسى و زنان سالم انجام شد.يافته هاى اين يثزوهش حاكى از آن بود كه ميانگين نمره در تعدادى از 
كمترى آوردند به دنبال دروغ خودشان، اثرات ناهماهنكى شناختى كلاسيك را به نمايش كذاشتند درد حالى كه شركت كنند گانى كه ويز كىهاى بيمار گون بالايى داشتند، اين طور نبودند. در افراد داراى ويز كى دهاى

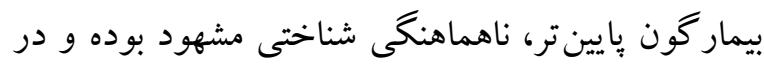

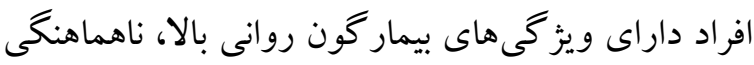
شناختى مشهود نبوده است. اين در حالى است كه يافتهاى بزّوهش حاضر نشان داد كه برانخيختخى بالا و

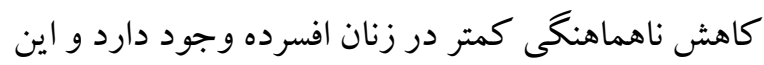
حاكى از ناهماهنكى شناختى كلى بالاتر در زنان افسرده

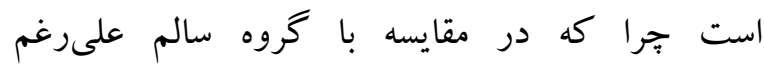
برانگيختخى بالا تلاشى براى كاهش ناهماهنگى شناختى

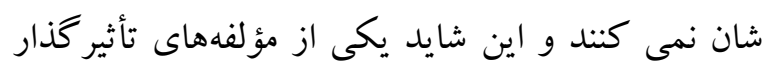
در افسردگىشان باشد جرا كه ماندن در لهالت برانكيختخى و عدم تلاش براى رفع ناهماهنكى ممكن است منجر به بالا رفتن تحريف هاى شناختى شود

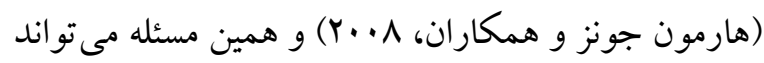
دليل برانگيختخى بيشتر و كاهش ناهماهنكى كمتر زنان افسرده را در مقايسه با گرووه سالم توجيه نمايد. يافته هاى "يخوهش حاضر همجينين با يافته هاى استدلر و آندرسون'

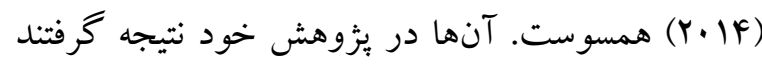
كه افراد افسرده در مقايسه با افراد غير افسرده احساس كناه بيشترى مى كنند و توانايى كمترى براى ناديده كرفتن حوادث كم اهميت دارند و به شكل كلى يافته ها حاكى از آن بود كه افراد افسرده به ميزان بيشترى

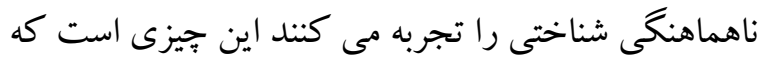
در يزٔوهش حاضر نيز به خوبى نشان داده شد بالا بودن
فردگرايى قابل توجه است ميزان اين دو نمره در گروه بهنجار بيشتر از گروه افسرده بوده است و در خصوص تبيين آنها مى توان همسو با ليبمن و همكاران (Yll) كفت كه يِخيرى فر آيند مكرر بِيش هزينه و سود در روابط بين فردى است و فرد بدينوسيله زمانى كه بداند هزينهاى روابط اجتماعى بيشتر از سود آنهاست اقدام به تركك رابطه كند و شايد اين مكانيسمى ساز گار انه باشد كه فرد كمتر آسيب بيند به همين دليل مى توان كفت شايد يكى از مؤلفههاى مهم در فر آيند افسردگى همين

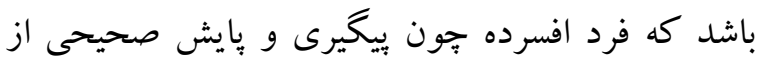

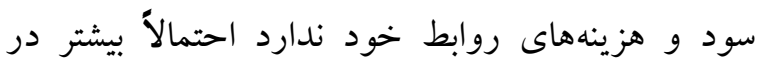
روابط مبتنى بر نابر ابرى سود و زيان مىماند و همين مسئله

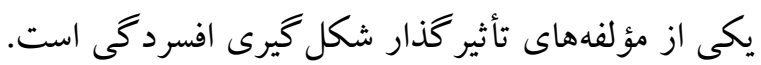
از سوى ديخر فردگرايى كه به عنوان رجحان براى خوداتكايى و سرمايه گذارى اندك (ليبمن و همكاران، (Y.1) تعريف شده نيز در افراد بهنجار بالاتر بود و اين مسئله شايد يادآور اين موضوع باشد كه افراد افسرده در روابط بين فردى بيشتر به ديخران متكى هستند و كمتر به خود متكى هستند و اين نكته دليل تفاوت بين دو گروه يافتهاى اين بثزوهش همجينين نشان داد كه ميانگين نمره

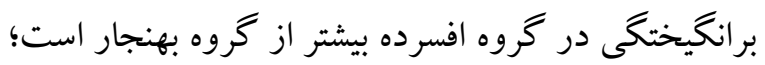
اما در زير مقياس كاهش ناهماهنگى ميانگين نمره گروه

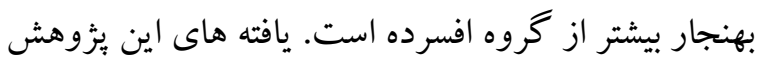

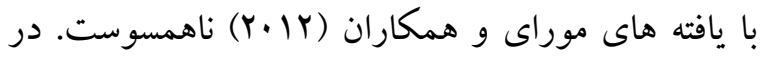
تحقيق آنها اثر اختلالات فكرى و روانى در ناهماهنكى شناختى را مورد بررسى قراردادند، اين نتيجه به دست آمد كه شركت كنند گانى كه در فرم كوتاه مقياس اختلالات فكر و روانى خود-گزارشى لونسون نمرات

\footnotetext{
${ }^{1}$ - Stalder, Daniel R. Anderson, Kyle M
} 
depression. 3rd ed. New York, NY: Guilford Press; Cognitive vulnerability-stress models of depression in a self-regulatory and psychobiological context; pp. 268-294.

American Psychiatric Association. (2013). Diagnostic and statistical manual of mental disorders (5th ed.). Washington, DC.

Boschloo L, Schoevers RA, Beekman AT, Smit JH, Van Hemert AM, Penninx BW. (2014). The four-year course of major depressive disorder: the role of staging and risk factor determination. Psychother Psychosomat. 83:279-88. 10.1159/000362563 [PubMed] [CrossRef] [Google Scholar]

Carey TA. (2008). Conflict, as the Achilles heel of perceptual control, offers a unifying approach to the formulation of psychological problems. Counselling Psychology Review. 23:5-16. [Google Scholar] [Ref list]

Egam, LC, Bloom P, \& Santos LR. (2010). Choiceinduced preferences in the absence of shoice: Evidence from a blind two choice paradigm with young children and capuchin monkeys. Journal of Experimental Social Psychology, 46(1), 204-207.

Eidelman P, Jensen A, \& Rappaport LM. (2019). Social support, negative social exchange, and response to case formulation-based cognitive behavior therapy, journal Cognitive Behaviour Therapy 48,(2) pages 146-161.

Feixas G, Montesano A, Compañ V, Salla M, Dada G, Pucurull O, Trujillo A, Paz C, Muñoz D, Gasol M, Saúl LÁ, Lana F, Bros I, Ribeiro E, Winter D, Carrera-Femández MJ, \& Guardia J. (2014). Cognitive conflicts in major depression: between desired change and personal coherence. The British joumal of clinical psychology, 53(4), 369-385. https://doi.org/10.1111/bjc.12050.

Ferrari AJ, Charlson FJ, Norman RE, Patten SB, Freedman G, Murray CJ, Vos T, Whiteford HA .(2013). Burden of depressive disorders by country, sex, age, and year. findings from the global burden of disease study 2010. PLoS Med. 2013 Nov; 10(11):e1001547.

$$
\begin{aligned}
& \text { سطح برانگيختخى تداعى گر ناتوانى در ناديده گرفتن } \\
& \text { حوادث كم اهميت است. }
\end{aligned}
$$

\section{نتيجه كيرى}

در كل نتايج ئزوهش حاضر نشان داد كه زنان فاقد افسردگى در مؤلفهاى ييخيرى و فردگرايى نمرات

بالاترى كسب كردند و اين نشان از آن است كه به شكل

متداوم ترى در حال سنجش سود و زيان ماندن در روابط اجتماعى هستند و همجينين با اتكاى بيشتر به خود در روابطشان مستقلانه تر عمل مى كنند و به نظر مىرسد اين

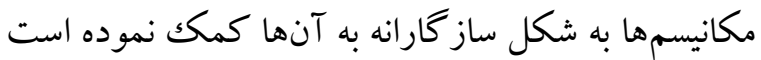
از سوى ديخر زنان افسرده برانگيختى بالاتر و كاهش ناهماهنكى شناختى كمترى گز ارش كردند كه حاكى از آن است كه در مقابله با ناهماهنگىها بيشتر در حالت برانگيختخى قرار مى گيرند، اما به دليل ضعف در حل ناهماهنكى و ناديده گيرى آنها كاهش ناهماهنكى شناختى كمترى را تجربه مى كنند و اين مسئله نيز مىتواند به عنوان يكى از دلايل اختلالشان نقش ايفا كند؛لذا به لهيه بالينگران توصيه مى شود در كار با زنان داراى اختلال

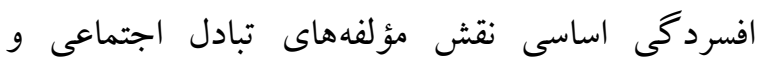
ناهماهنكى شناختى رادر نظر داشته باشند.

$$
\begin{aligned}
& \text { سياسگزارى } \\
& \text { نويسنده مقاله مراتب تشكر و قدرانى خود را از تمامى } \\
& \text { شر كت كنند كان در بثروهش و كلينيك هايى كه در انجام } \\
& \text { اين يُزوهش ما را همكارى كردند اعلام مى كند. }
\end{aligned}
$$

\section{References}

Abramson LY, Alloy LB, Hankin BL, Haeffel GJ, MacCoon DG, Gibb BE, Gotlib IH, Hammen CL. (2002). Handbook of 
Harmon-Jones E, Harmon-Jones C, Feam M, Sigelman JD, Johnson P. (2008). Left frontal cortical activation and spreading of alternatives: tests of the action-based model of dissonance. J Pers Soc Psychol. 2008 Jan;94(1):1-15. doi: 10.1037/00223514.94.1.1.

Josefsson A, Vikström J, Bladh M, \& Sydsjo G. (2019). Major depressive disorder in women and risk for future generations: population-based threegeneration study. BJPsych open,5(1), e8. https://doi.org/10.1192/bjo.2018.83.

Leybman MJ, Zuroff DC, \& Foumier MA. (2011). Social exchange styles: Measurement, validation, and application. European Joumal of Personality, 25(3), 198-210.

Nordentoft M, Wahllbeck K, Hällgren J, Westman J, Osby U, Alinaghizadeh $\mathrm{H}$, et al. (2013). Excess mortality, causes of death and life expectancy in 270,770 patients with recent onset of mental disorders in Denmark, Finland and Sweden.PLoS ONE8:e55176. 10.1371/joumal.pone.0055176 [PMC free article] [PubMed] [CrossRef] [Google Scholar]

Richards D. (2011). Prevalence and clinical course of depression: a review. Clin Psychol Rev. 31:1117-25. 10.10166j.cpr.2011.07.004 [PubMed] [CrossRef] [Google Scholar]

Saffarinia M, \& Zandi A. (2010). The Investigation of Psychometric Characteristics of a standardized questionnaire - reducing inconsistencies DARQ Harmon - Jones in payame noor Students [in Persian].

Saffarinia M. (2017). The Investigation of Psychometric Characteristics of Social Exchange Styles Scale in Iranian Population. Industrial and Organizational Psychology Studies, 4(1), 1-18. doi: 10.22055/jiops.2018.23881.1065 [in Persian]

Schaich A, Heikaus L, Assmann N, Kohne S, Jauch Chara K, Huppe M, Wells A, Schweiger U, Klein JP, \& Fassbinder E. (2018). PRO"MDD Study Protocol: Effectiveness of Outpatient Treatment Programs for Major Depressive Disorder: Metacognitive Therapy vs. Behavioral Activation a Single-Center Randomized Clinical Trial.Frontiers in psychiatry, 9 , 584. https://doi.org/10.3389/fpsyt.2018.00584.

Stalder DR, \& Anderson KM. (2014). Are depressed individuals more susceptible to cognitive dissonance? Current Research in Social Psychology, 22, Article 6. 